\title{
Modeling the Distribution of Agricultural Drought by Means of Soil Water Deficit
}

\author{
Capriolo Alberto Daniel ${ }^{1} \&$ Scarpati Olga Eugenia ${ }^{1,2}$ \\ ${ }^{1}$ National Research Council, CONICET, Buenos Aires, Argentina \\ ${ }^{2}$ Geography Department, La Plata National University, Argentina \\ Correspondence: Capriolo Alberto Daniel, National Research Council, CONICET, Paraguay 2155, Floor 17, \\ Buenos Aires, PC 1121, Argentina. E-mail: albertocapriolo@yahoo.com.ar
}

Received: May 10, 2012 Accepted: May 25, 2012 Online Published: June 16, 2012

doi:10.5539/eer.v2n2p1 URL: http://dx.doi.org/10.5539/eer.v2n2p1

\begin{abstract}
The extreme hydrologic events in Buenos Aires province (Argentina) had been a constant in its social economic development. Their impacts mainly over the agriculture have been studied with different scales and point of views. In spite of that, there is a lack of studies of their temporal and spatial distribution in Argentina. Drought is initiated by a reduction in precipitation. The time requires for a lack of rainfall to create a significant deficit in the supplies is variable and could vary from a few weeks to several years. This paper studies the soil water deficit from 1969 to 2008 in the whole Buenos Aires province $\left(307,571 \mathrm{~km}^{2}\right)$ which is divided in 16 sectors according its basins (National Water Resources) and with soil water balance using soil data obtained "in situ". It was performed using the evapotranspitation formula of Penman - Monteith and considering the soil water constants: Field Capacity, Soil Water Moisture and Soil Wilting Point for all the different types of soils of the region. For the statistical study, the obtained data series of soil water deficit were adjusted by means of the theoretical Normal Cubic-root probability distribution. An annual threshold value of $200 \mathrm{~mm}$ is considered because it is an ecological limit and upper which the drought is the consequence. The intensity of it has been arbitrary classified in: mild, moderate, severe and extreme according the annual values reached. Mann Kendall statistical test was performed and significance trends at levels $0.1,0.05$ and 0.01 were found.
\end{abstract}

Keywords: soil water deficit, drought, Buenos Aires province, soil water balance

\section{Introduction}

Drought is a period of abnormally dry weather sufficiently prolonged for the lack of precipitation to cause a serious hydrological imbalance (Hunt et al., 2009).

We really believe that understanding different concepts of droughts it will be helpful for developing models to investigate different drought properties as its severity.

Drought is a natural, reoccurring, worldwide phenomenon that is responsible for widespread losses mainly in agriculture. It occurs in virtually all climatic zones, such as high as well as low rainfall areas and is mostly related to the reduction in the amount of precipitation received over an extended period of time, such as a season or a year (Mishra \& Singh, 2010). Some characteristics of others climate elements like high temperatures; high winds; low relative humidity; timing and characteristics of rains, including distribution of rainy days during crop growing seasons, intensity and duration of rain, and onset and termination, play a significant role in the occurrence of droughts and influencing the evapotranspitation.

The droughts are generally classified into four categories (Wilhite \& Glantz, 1985; American Meteorological Society, 2004), which include: meteorological, hydrological, agricultural and socio-economic drought.

This paper studies a component of soil water balance: the soil water deficit, because the interest is centred in agricultural drought. It usually refers to a period with declining soil moisture and consequent crop failure without any reference to surface water resources. A decline of soil moisture depends on several factors which affect meteorological and hydrological droughts along with differences between actual evapotranspiration and potential evapotranspiration. Plant water demand depends on prevailing weather conditions, biological characteristics of the specific plant and stage of growth, and the physical and biological properties of soil (Scarpati et al., 2011). 
The Crop Moisture Index (CMI) developed by Palmer (1968) is an index specific to agricultural drought that is based on comparing drought conditions at the beginning of a week with the recharge of soil water or ET deficit during the week.

Other drought indices have arisen to compensate for some weaknesses in the Palmer Index. Narasimhan and Srinivasan (2005) developed soil moisture deficit index (SMDI) and evapotranspiration deficit index (ETDI) based on weekly soil moisture and evapotranspiration simulated by a calibrated hydrologic model, respectively. The drought indices were derived from soil moisture deficit and evapotranspiration deficit and scaled between -4 and +4 for spatial comparison of droughts, irrespective of climatic conditions.

One of the most popular drought indices in the last decade has been the Standard Precipitation Index (SPI), Mishra and Singh (2011) related that McKee et al. in 1993, developed the SPI as an alternative to the Palmer Index for Colorado using historical precipitation data to compute a probability distribution of the monthly and seasonal precipitation totals. The precipitation probabilities were then normalized using a Gaussian function. The SPI is a dimensionless index where negative values indicate drought and positive values indicate sufficient moisture. Magnitude and duration of drought, as well as the probability of emergence from drought, were determined from the SPI index. One major advantage of the SPI, specifically over the widely used Palmer Drought Index, is its spatial invariance across different climate regions.

Soil moisture is a significant hydrological variable related to floods and droughts and plays an important role in the process of converting precipitation into runoff and groundwater storage. A soil moisture deficit results in more infiltration and little runoff when it is followed by precipitation. However, high soil moisture results in overland runoff and possible flooding during intense precipitation. In addition, high soil moisture promotes vegetation growth in the summer and this leads to high evapotranspiration. Therefore, soil moisture controls the interaction of the land with the atmosphere (Tang \& Piechota, 2009).

Water demand and water balance indices would be more useful in assessing agricultural drought than the water supply indices frequently used for meteorological drought.

According to Mishra and Singh (2010), all of these indices can be useful and all indices have inherent strengths and weaknesses. However, none of the mentioned indices directly uses soil water observations as part of the index. A soil moisture index (SMI) was developed based on the actual water content and known field capacity and wilting point, with 8 years of soil water observations at sites under grass cover throughout Nebraska (Hunt et al.,2009). The SMI can identify a quick onset of agricultural drought by demonstrating the observed dryness of a soil relative to the plant's ability to extract water. It is known that the evapotranspiration became limiting below the midpoint between Field Capacity and Wilting Point or Permanent Wilting Point.

Mishra and Singh (2011) mentioned that the climate indices like El Nino- Southern Oscillation (ENSO), which is numerically defined by the Southern Oscillation Index (SOI), Sea Surface Temperature (SST), North Atlantic Oscillation (NAO), Pacific Decadal Oscillation (PDO), Inter-decadal Pacific Oscillation (IPO) and Atlantic Multidecadal Oscillation (AMO) are used in addition to the hydro-meteorological variables for long-lead drought forecasting.

In South America Tang and Piechota (2009) mentioned the studies done by Poveda and Mesa in Colombia using ENSO, precipitation and soil moisture. In Argentina there are several studies analysing ENSO and the soil water balance and its components as Spescha et al. (2004), Scarpati et al. (2004, 2007 a, 2007 b and 2009).

\subsection{Buenos Aires Province}

The climate of Buenos Aires province is temperate and humid, with warm summers and cool winters. Mean annual temperatures oscillate between $13^{\circ} \mathrm{C}$ and $16^{\circ} \mathrm{C}$. The warmest month (January) has mean monthly temperature reaching 20 to $23^{\circ} \mathrm{C}$ and the coldest month (July) varying between 7 and $9^{\circ} \mathrm{C}$.

Annual precipitation ranges from $1,000 \mathrm{~mm}$ in the north-east to $700 \mathrm{~mm}$ in the south-west. Precipitation is usually generated by the meeting of the warm and humid air mass from the semi-permanent anticyclone over the Atlantic Ocean and the cold air mass from the south-west.

The region constitutes one of the major food producing regions of Argentina. Most agricultural activities are carried out under rain fed conditions and therefore, crop production is dependent on rainfall during the growth season and they are strongly affected by climatic variability. Furthermore, against the very unfavourable economic scenarios of the last decades, farmers have been struggling to maintain their income by continuously trying to increase yields by intensifying their production systems, which have often become more vulnerable to climate variability and potential climate change. 
According to Barros et al. (2000) subtropical Argentina (where the study region is located), Paraguay and South of Brazil have experienced more precipitation during summer with high interannual variability in the last decades of XX century. In this season, a convergence zone at low level, divergence in high level and an intense convection is developed north of this region. It is known as South Atlantic Convergence Zone (SACZ) and seemed to have a relationship with the interannual precipitation variability.

In 2007 Magrin et al. observed a negative non significant trend for winter precipitation in some sites located in the province of Buenos Aires.

\section{Materials and Methods}

\subsection{Study Area}

Figure 1 represents the geographical location of the Buenos Aires province, Figure 2 its hydrology and Figure 3 and Table 1 the drainage areas or sectors (S1 to S16) of this province according with the Atlas digital de los recursos hídricos superficiales de la República Argentina (National Water Resources, 2002).

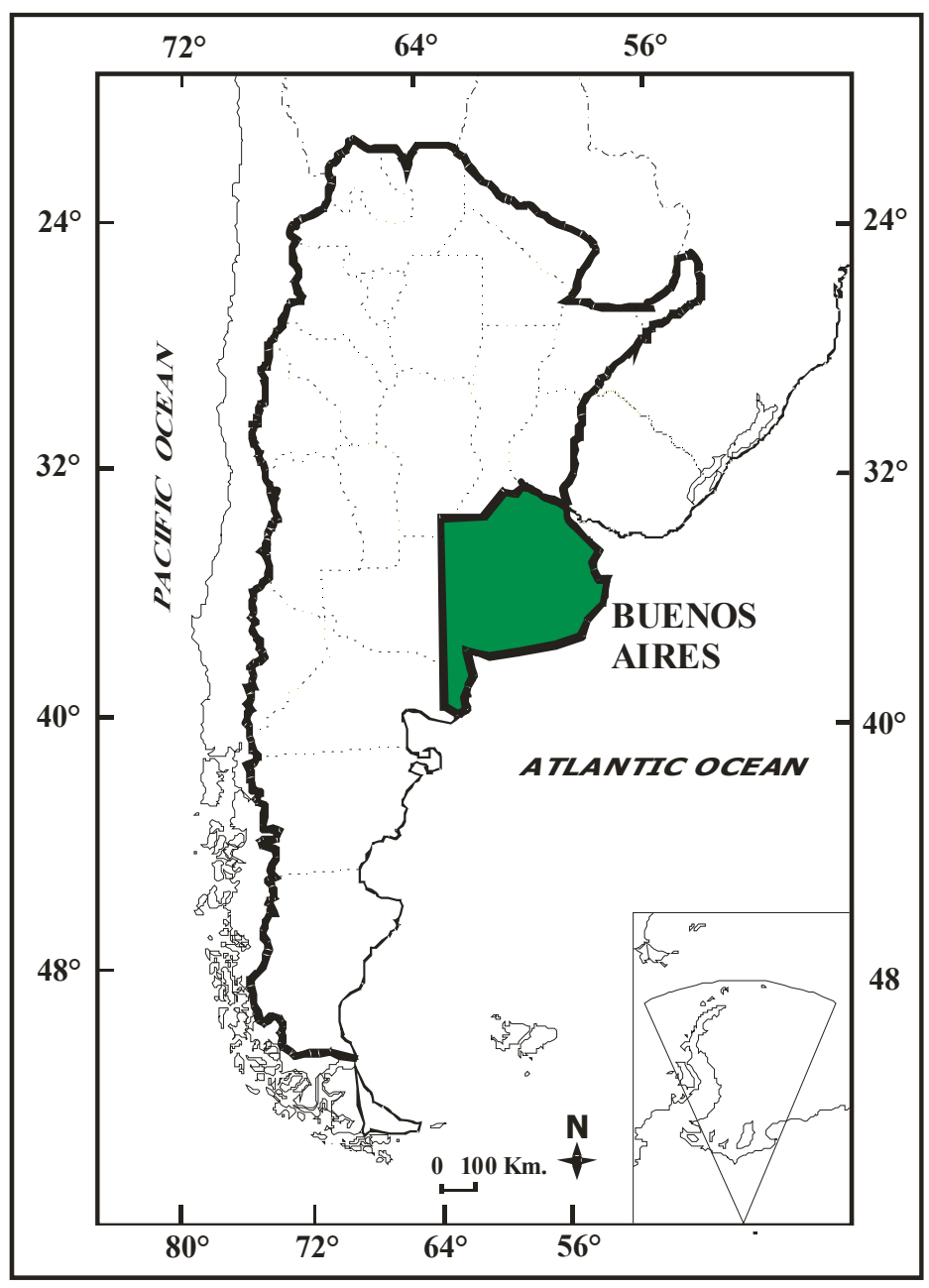

Figure 1. Location of Buenos Aires province, Argentina 


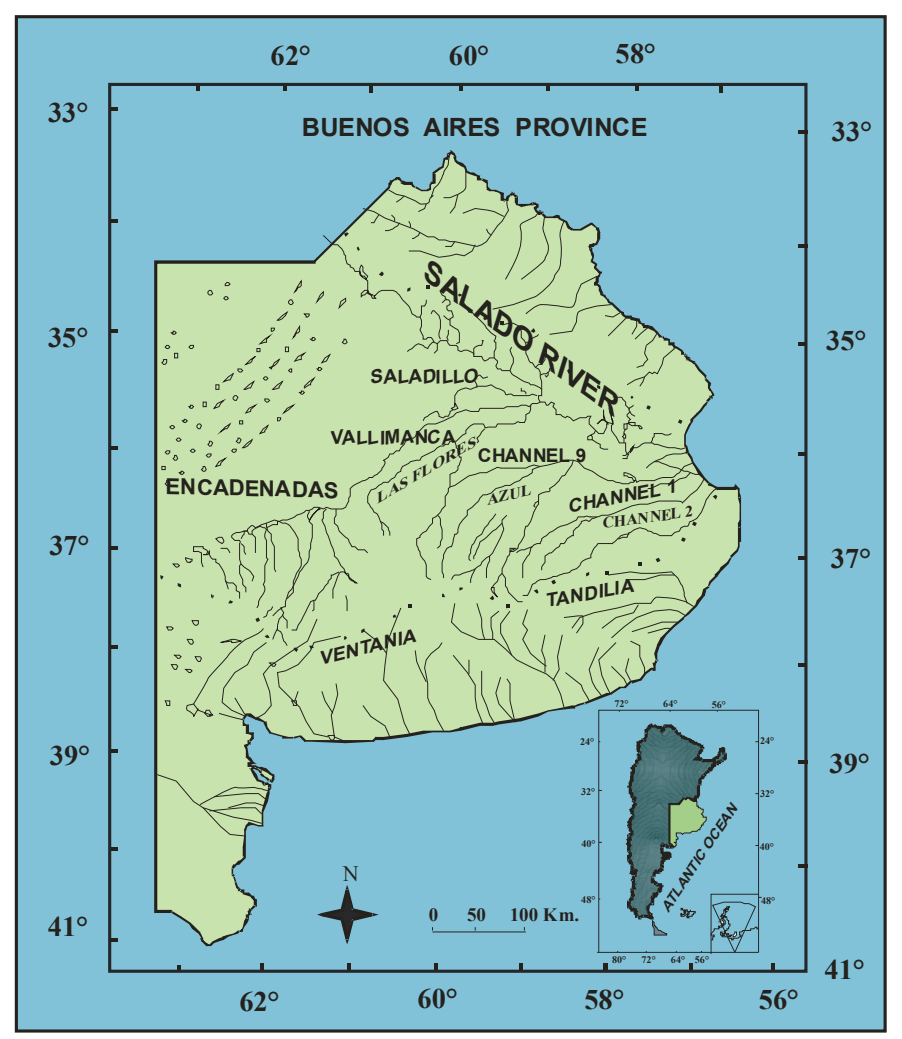

Figure 2. Buenos Aires province and its hydrology

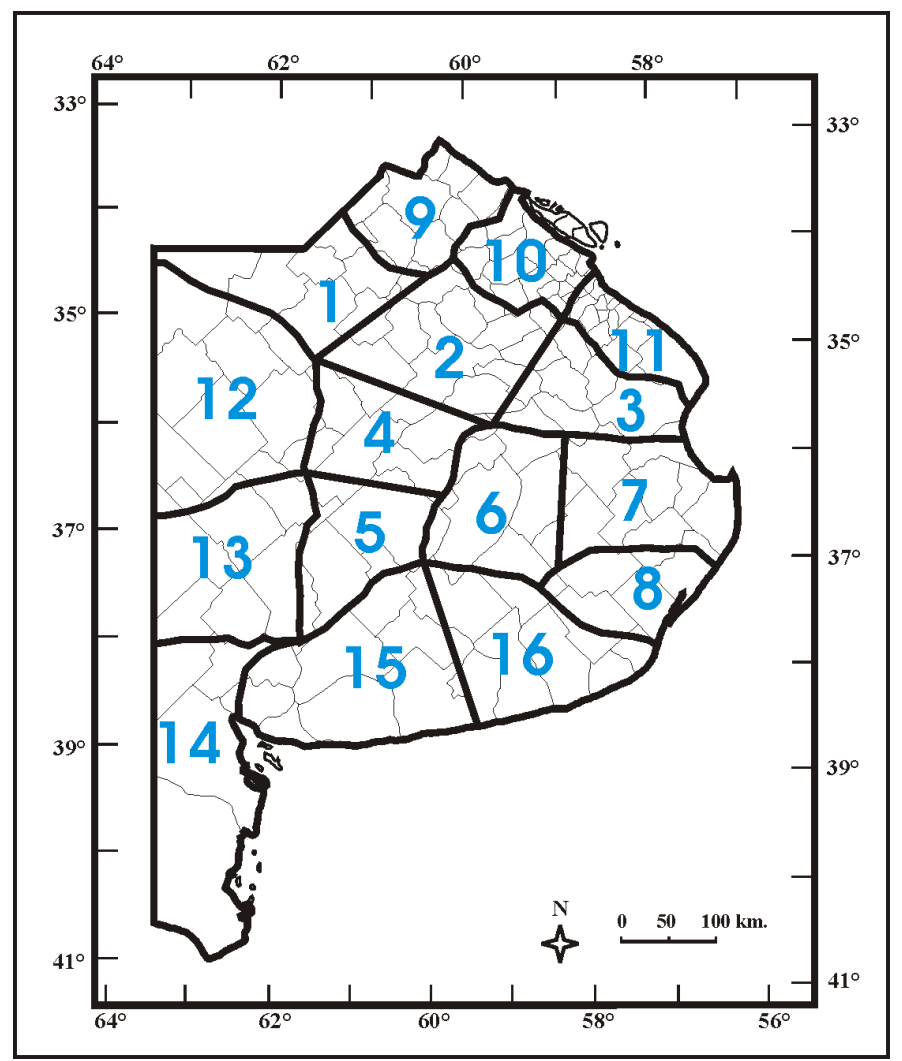

Figure 3. Buenos Aires province and its drainage areas 
Table 1. Drainage areas studied in the Buenos Aires province

\begin{tabular}{ll}
\hline Drainage area & \\
\hline S1 & Northwestern area of the Salado River basin \\
S2 & Central area of the Salado River basin \\
S3 & Salado River mouth \\
S4 & Southern area of the Salado River basin and northern area of Vallimanca River basin \\
S5 & Southern area of the Salado and Vallimanca Rivers basins \\
S6 & Western Channels area at south of the Salado River basin \\
S7 & Channels area at south of the Salado River \\
S8 & Southeastern basin and streams \\
S9 & Arrecifes River basin \\
S10 & Northeastern streams basin \\
S11 & Drainage basin of the La Plata River at the South of Samborombon River \\
S12 & Region without surface drainage \\
S13 & Lagoon area at the Southwest \\
S14 & Small rivers and streams with Atlantic drainage \\
S15 & Basins and Streams of South (to west) \\
S16 & Basins and Streams at South (to east) \\
\hline
\end{tabular}

\subsection{Data and Meteorological Stations}

Daily precipitation data for the period 1969-2008 were provided by the National Meteorological Service - SMN (29 stations) and by the National Institute of Agronomic Technology - INTA (5 stations). The meteorological stations were selected according to their long record, homogeneity and historical development. Figure 4 shows the studied area with the meteorological stations used listed in Table 2.

Table 2. Denomination and code of the meteorological stations

\begin{tabular}{clcl}
\hline Number & \multicolumn{1}{c}{ Station } & Number & \multicolumn{1}{c}{ Station } \\
\hline $\mathbf{1}$ & San Pedro INTA & $\mathbf{1 8}$ & Daireaux \\
$\mathbf{2}$ & Pergamino INTA & $\mathbf{1 9}$ & Santa Teresita \\
$\mathbf{3}$ & Junín & $\mathbf{2 0}$ & Azul \\
$\mathbf{4}$ & San Miguel & $\mathbf{2 1}$ & Olavarría \\
$\mathbf{5}$ & Mariano Moreno & $\mathbf{2 2}$ & Tandil \\
$\mathbf{6}$ & Aeroparque J. Newbery & $\mathbf{2 3}$ & Villa Gesell \\
$\mathbf{7}$ & Buenos Aires & $\mathbf{2 4}$ & Coronel Suarez \\
$\mathbf{8}$ & Ezeiza & $\mathbf{2 5}$ & Laprida \\
$\mathbf{9}$ & General Villegas & $\mathbf{2 6}$ & Pigüé \\
$\mathbf{1 0}$ & La Plata & $\mathbf{2 7}$ & Benito Juárez \\
$\mathbf{1 1}$ & Nueve de Julio & $\mathbf{2 8}$ & Balcarce INTA \\
$\mathbf{1 2}$ & Punta Indio & $\mathbf{2 9}$ & Bordenave INTA \\
$\mathbf{1 3}$ & Pehuajó & $\mathbf{3 0}$ & Coronel Pringles \\
$\mathbf{1 4}$ & Trenque Lauquen & $\mathbf{3 1}$ & Mar del Plata \\
$\mathbf{1 5}$ & Las Flores & $\mathbf{3 2}$ & Tres Arroyos \\
$\mathbf{1 6}$ & Bolivar & $\mathbf{3 3}$ & Bahía Blanca \\
$\mathbf{1 7}$ & Dolores & $\mathbf{3 4}$ & Hilario Ascasubi INTA \\
\hline
\end{tabular}




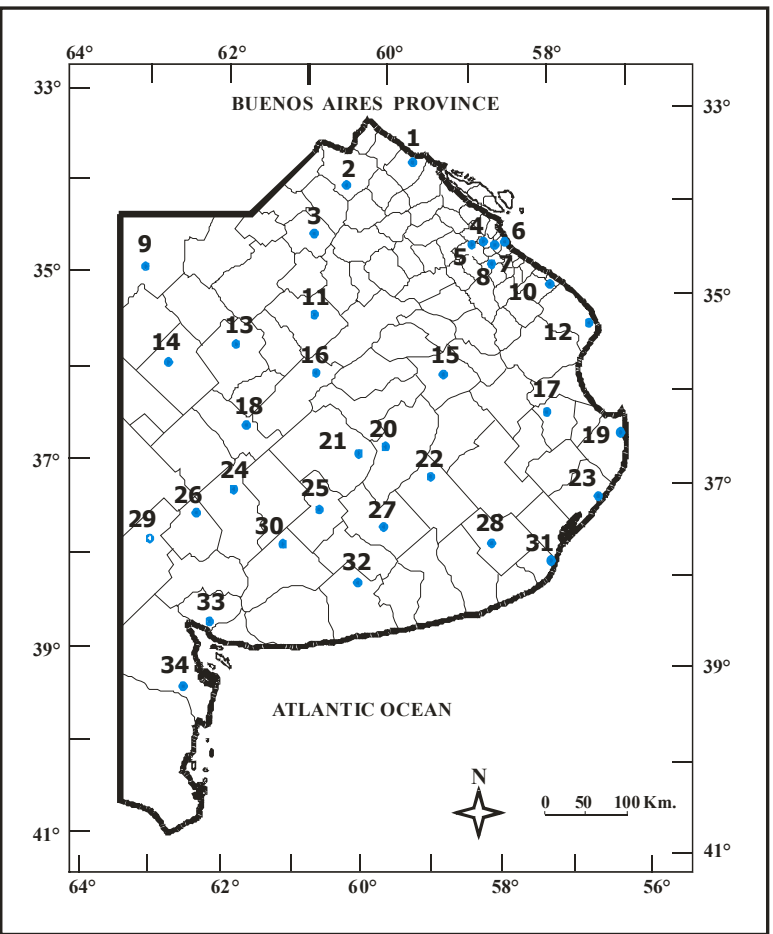

Figure 4. Meteorological stations location

\subsection{Assumed Concepts Referred to Soil Water Balance}

The spatial and temporal variability of soil water storage was examined using the balance of Forte Lay et al. (2008) which is based on Thornthwaite and Mather daily soil water balance method, using measured precipitation from the meteorological stations and daily mean reference evapotranspiration. The normal daily mean reference evapotranspiration was estimated by the Penman-Monteith formula (Allen et al., 2004).

Equation 1 shows the model of soil water balance used:

$$
P P-E P+\triangle S t+S u+D e f=O
$$

where:

$P P$ : daily precipitation

$E P$ : mean reference evapotranspiration

$\Delta S t$ : Soil water storage variation

$S u$ : Soil water surplus

Def: Soil water deficit

The soil hydrologic constants: Field Capacity (FC) and Permanent Wilting Point (PWP) were calculated with soil data measured "in situ" and used by Forte Lay et al. (2008).

Total soil moisture can be divided in two equal parts: the available soil water content and the non useful water as can be seen in Figure 5.

The available soil moisture, as well, can be divided in two parts: the optimum soil water content (50 to $100 \%$ of useful water) and the conditional drought level ( 0 to $50 \%$ of useful water).

Absolute drought is when the useful water is $0 \%$. PWP is the limit between the last one and the conditional drought level and represents the upper limit of drought according to Scarpati et al. (2011). 


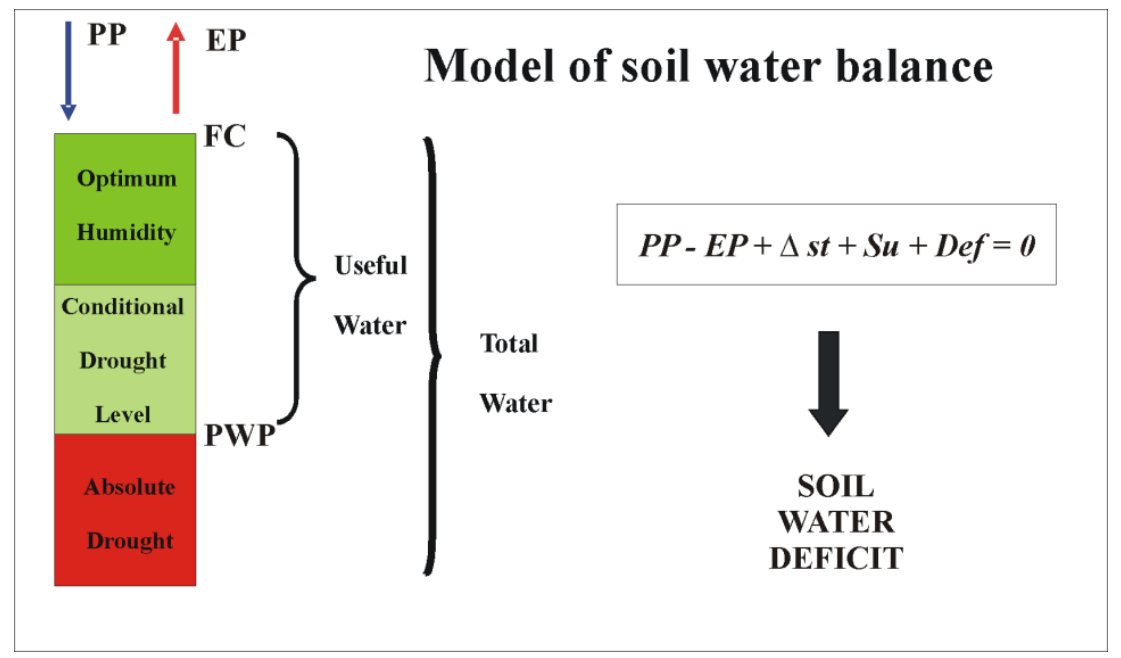

Figure 5. Soil water balance

All these parameters vary according the soil texture and the effective depth (root zone), which depends of a restrictive horizon existence. Some soils with high effective depth reach one meter or more and have high FC. Other soils, with low effective depth root zone, only achieve lower depths and so the FC diminishes.

The soil water balance was realized for all the used stations, for every year of the studied period and so, all the annual areal values of soil water deficit were obtained.

\subsection{Maps Construction}

The maps showing the soil water deficit as results of soil water balance of each meteorological station, for every year of the studied period were performed using the software SURFER 8.0. This mapping software allows the construction of isolines maps using its kriging option (the Point Kriging estimates the values of the points at the grid nodes).

\subsection{Soil Water Deficit}

The obtained maps permit the observation of the annual soil water deficit spatial distribution. Then, the temporal distribution was analyzed considering an average areal value for each drainage area of Table 1 and for each year.

An annual mean areal value of $200 \mathrm{~mm}$ of soil water deficit is considered as threshold, upper which the damage for drought is the consequence. This value is considered because it is an ecological limit.

In this paper the drought has been classified in mild, moderate, severe and extreme according the annual soil water deficit (ASWD) values deficit reached as can be seen bellow:

\begin{tabular}{|c|c|c|c|c|}
\hline ASWD $(\mathrm{mm})$ & $\leq 200$ & $\geq 200$ and $\leq 300$ & $\geq 300$ and $\leq 400$ & $\geq 400$ \\
\hline Drought & Mild & Moderate & Severe & Extreme \\
\hline
\end{tabular}

\subsection{Statistical Analysis}

The non parametric test Mann-Kendall is applied for all the data series, and then, an Excel template-MAKESENS-is used for detecting and estimating trends in the time series of annual values of soil water deficit (Salmi et al., 2002). The procedure is based on the nonparametric Mann-Kendall test for the trend and the nonparametric Sen's method for the magnitude of the trend. First, the Mann-Kendall test is applicable to the detection of a monotonic trend of a time series with no seasonal or other cycle and then the Sen's method uses a linear model for the trend (Equation 2). In MAKESENS the tested significance levels $\alpha$ are 0.001, 0.01, 0.05 and 0.1 (Liu et al., 2009).

$$
f(t)=\mathrm{Q} t+\mathrm{B}
$$

where $\mathrm{Q}$ is the slope and $\mathrm{B}$ is a constant. 


\section{Results and Discussion}

The results are annual soil water deficit values, which represents accumulated water deficit distributed along the twelve mounts of the year.

Figure 6 is compound by five maps showing the annual soil water deficit of several years with drought. They presented big areas with different drought characteristics and localization. There are values upper than $400 \mathrm{~mm}$ and even more and areas with different amount of soil water deficit were scattered along the whole province.

The dry areas in 1979 were located mainly in the centre and east of the province, during 1989 at the north western area, in 1995 at west and some circles at north and centre of it. During 2008 almost the whole region had had problems and all the mentioned years, including 1999, presented high risk of drought at the southern part of the province. The soil water deficit values in 2008 were more important than during 1995 at the east (450 mm) and at the north $(550 \mathrm{~mm})$ of the province.

The maps were made in gradual red colour according with the severity of the event. All of them have the south of the province in dark red. These areas (S 14 and S15: Small Rivers and Streams with Atlantic drainage and Basins and Streams of South (to west)) are very susceptible to soil water deficit and always they are the first ones presenting this problem. The values started in S15 with $350 \mathrm{~mm}$ and finished in 1,100 mm in S14.

The rest of Buenos Aires province had different drought pattern marked in different tones of red. Drainage area or Sectors 8 (S8 or Southeastern basin and Streams basins) and S16 (Streams at south (to east)) in the mentioned years had 200- $250 \mathrm{~mm}$ of annual deficit but during 2008 reached more than $300 \mathrm{~mm}$. The drainage areas or sectors S1, S2, S3, S9, S10 and S11 (Northwestern area of the Salado River basin, Central area of the Salado River basin, Salado River mouth, Arrecifes River basin, Northeastern streams basin and Drainage basin of De La Plata River at the South of Samborombon River) in 1989 and 1999 had values between 200 and 350 mm, in 1995 they were close to 350 (with a little zone with $400 \mathrm{~mm}$ ) but in the last drought (2008) they oscillated between $350 \mathrm{~mm}$ and $500 \mathrm{~mm}$.

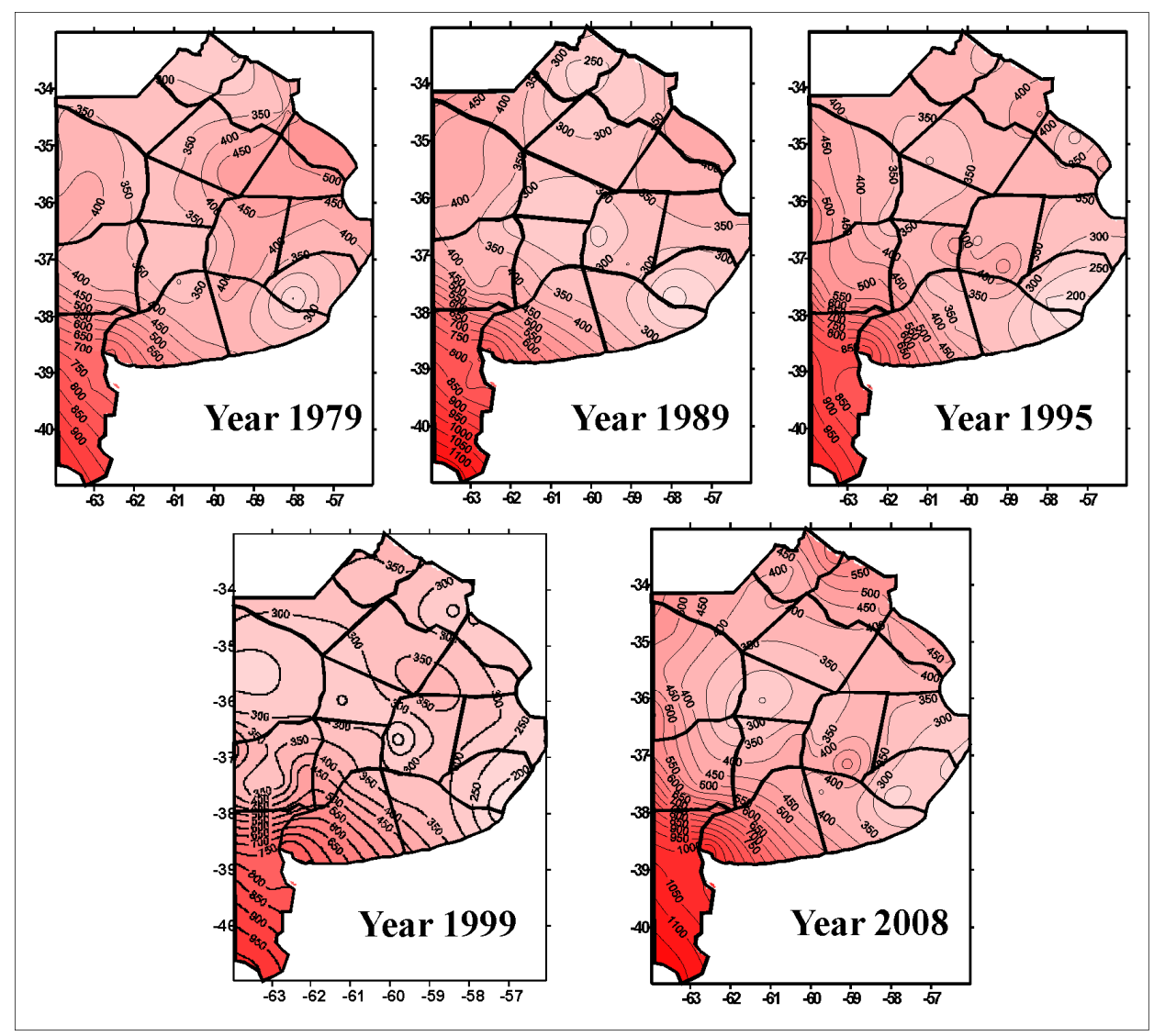

Figure 6. Annual soil water deficit 
The drainage areas S4, S5, S6 and S7 (Southern area of the Salado River basin and Northern area of Vallimanca River basin, Southern area of the Salado and Vallimanca Rivers basins, Western Channels area at south of the Salado River basin and Channels area at south of the Salado River) had deficit values oscillating between 250 and $450 \mathrm{~mm}$.

The areas S12 and S13 (Region without surface drainage and Lagoon area at the Southwest) presented a gradation of $150 \mathrm{~mm}$ from north to south, but in 2008, it was of $350 \mathrm{~mm}$ (from $400 \mathrm{~mm}$ in the north to $750 \mathrm{~mm}$ at the south).

Figure 7 shows the evolution of the soil water deficit for the whole province and for each drainage area during the forty studied years.

Figure 7 can be indicating the end of a wet period after a long number of humid years and so, a climatic variability.

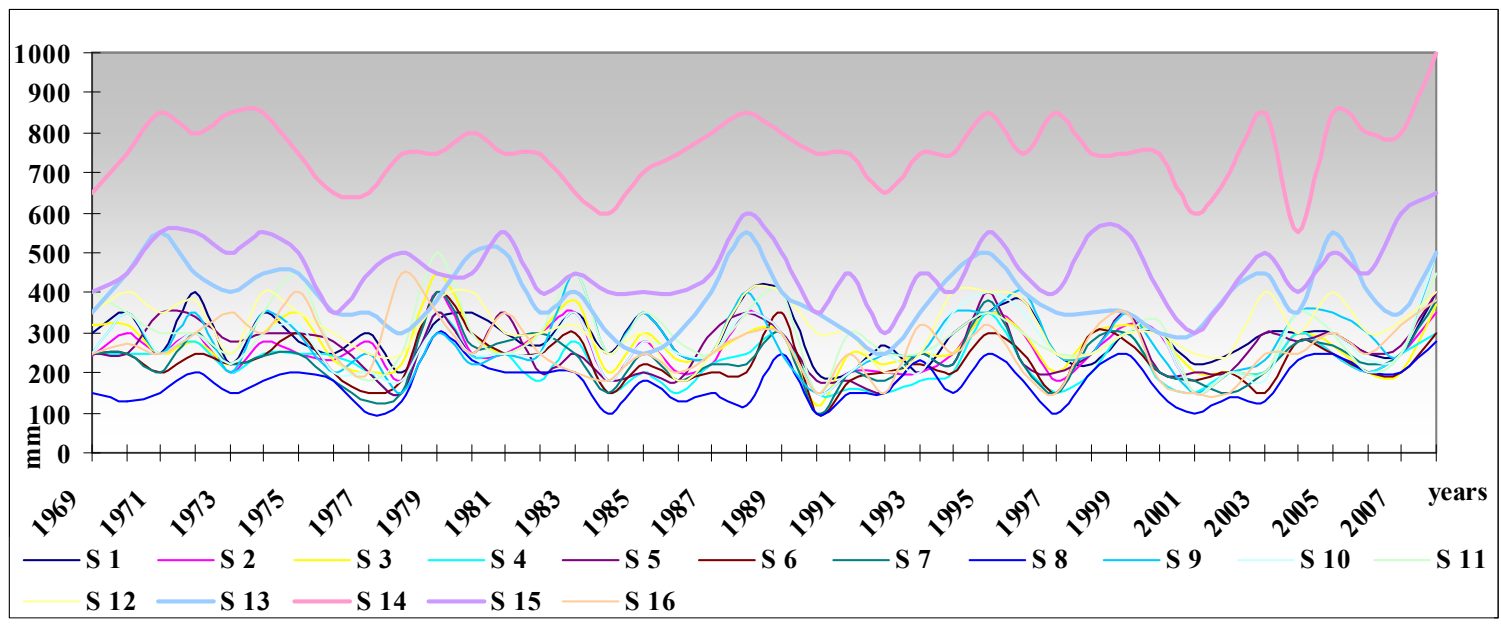

Figure 7. Soil water deficit of the year 1969 to 2008

Sectors 14 and 15 (Small rivers and Streams with Atlantic drainage and Basins and Streams of South (to west)) present the highest values and S8 (Southeastern basin and streams) the lowest one. The drainage area S13 (Lagoon area at the Southwest) accompanies them with not so high values.

Table $\mathrm{N}^{\circ} 3$ shows the results of the applied classification and the number of mild, moderate, severe and extreme droughts for each analyzed sector during the studied period.

All the different drainage areas of Buenos Aires province have had drought of different severity in some moment of the year in the whole analyzed period. Table 3 presents in grey colour the type of drought with high presence for each sector.

The drainage areas: Lagoon area at the Southwest (S13), Small rivers and streams with Atlantic drainage (S14) and Basins and Streams of South (to west) (S15) presented extreme drought - equal or higher than $400 \mathrm{~mm}$. Drainage basin of De La Plata River at the South of Samborombon River (S11), Region without surface drainage (S12) and Basins and Streams at South (to east) (S16) were the areas which presented mainly severe droughts equal or higher than $300 \mathrm{~mm}$. With the exception of the sectors S1, S2, S3, S4, S5, S6, S7, S9 and S10, all the drainage areas had mainly moderate droughts. Southeastern basin and Streams (S8) had mild and moderate droughts.

Southern area of the Salado River basin and Northern area of the Vallimanca River basin (S4) and the Southeastern basin and Streams (S8) had never droughts classified as extreme.

The temporal distribution of the soil water deficit $(\mathrm{mm})$ for the different drainage areas of Buenos Aires province and the results of the Makesens test can be seen at Table 4 .

The results show the presence or not of a positive or a negative trend at the different time scales used: 1969-2008, 1969-1978, 1979-1988, 1989-1998 and 1999-2008. 
Table 3. Distribution of the different types of droughts at the different drainage areas

\begin{tabular}{ccccc}
\hline \multirow{2}{*}{ Drainage Area } & \multicolumn{4}{c}{ Drought } \\
\cline { 2 - 5 } & Mild & Moderate & Severe & Extreme \\
\hline S1 & 0 & 19 & 17 & 4 \\
S2 & 5 & 22 & 12 & 1 \\
S3 & 1 & 21 & 17 & 1 \\
S4 & 11 & 23 & 6 & 0 \\
S5 & 6 & 20 & 12 & 2 \\
S6 & 9 & 23 & 7 & 1 \\
S7 & 10 & 23 & 6 & 1 \\
S8 & 22 & 17 & 1 & 0 \\
S9 & 3 & 21 & 12 & 4 \\
S10 & 5 & 19 & 15 & 1 \\
S11 & 3 & 15 & 16 & 6 \\
S12 & 1 & 11 & 18 & 10 \\
S13 & 0 & 2 & 19 & 19 \\
S14 & 0 & 0 & 0 & 40 \\
S15 & 0 & 0 & 4 & 36 \\
S16 & 7 & 16 & 15 & 2 \\
Total/Area & $\mathbf{8 3}$ & $\mathbf{2 5 2}$ & $\mathbf{1 7 7}$ & $\mathbf{1 2 8}$ \\
\hline & & & &
\end{tabular}

Table 4. Temporal distribution of soil water deficit (mm)

\begin{tabular}{lccccc}
\hline \multirow{2}{*}{ Area } & \multicolumn{5}{c}{ Period } \\
\cline { 2 - 6 } & 1969 - 2008 & 1969 - 1978 & 1979 - 1988 & 1989 - 1998 & 1999 - 2008 \\
\hline S1 & $=$ & $\downarrow$ & $=$ & $\uparrow$ & $=$ \\
S2 & $=$ & $\downarrow$ & $\downarrow$ & $\uparrow$ & $=$ \\
S3 & $\downarrow$ & $\downarrow$ & $\downarrow$ & $\uparrow$ & $=$ \\
S4 & $=$ & $\downarrow *$ & $\downarrow$ & $\uparrow$ & $\uparrow$ \\
S5 & $=$ & $\downarrow$ & $\downarrow$ & $\uparrow$ & $\uparrow$ \\
S6 & $=$ & $\downarrow$ & $\downarrow^{*}$ & $\uparrow$ & $=$ \\
S7 & $=$ & $\downarrow$ & $\downarrow *$ & $\uparrow$ & $\uparrow$ \\
S8 & $\uparrow$ & $=$ & $\downarrow^{* *}$ & $=$ & $\uparrow$ \\
S9 & $=$ & $\downarrow$ & $=$ & $\uparrow$ & $\uparrow$ \\
S10 & $=$ & $\downarrow$ & $=$ & $\uparrow$ & $\uparrow$ \\
S11 & $\downarrow$ & $\downarrow$ & $\downarrow$ & $=$ & $\uparrow$ \\
S12 & $=$ & $\downarrow$ & $\downarrow$ & $\downarrow$ & $\uparrow$ \\
S13 & $=$ & $\downarrow$ & $\downarrow$ & $=$ & $\uparrow$ \\
S14 & $=$ & $=$ & $=$ & $=$ & $\uparrow$ \\
S15 & $=$ & $=$ & $=$ & $\uparrow$ & $\uparrow$ \\
S16 & $=$ & $\uparrow$ & $\uparrow$ & $=$ & $\uparrow$ \\
\hline
\end{tabular}

References: $\downarrow$ decrease, $\uparrow$ increase and $=$ no variation, + significance trend at $\alpha=0.1$ level, ${ }^{*}$ significance trend at $\alpha=0.05$ level and $* *$ significance trend at $\alpha=0.01$ level. 
The sector S8 (Southeastern basin and Streams) presents during 1969-2008 a little increase and S3 and S11 (Salado River mouth and Drainage basin of De La Plata River at the South of Samborombon River) have little diminution.

The drainage areas with low risk are situated mainly at east and north of the province, while sectors at west and south experienced always drought of different intensity and even so, they had been increased during the last studied period: $1999-2008$.

The events with statistical significance occurred between the years 1969-1988 and they are associated with an increase of precipitation.

The period 1989-2008 had no statistical significance but it can be seen a positive trend in almost all the areas.

\section{Conclusions}

Buenos Aires province experienced extreme hydrological events during the last decades, much of them implying risk (floods and droughts) and representing the costliest weather related natural hazards.

This study has shown different droughts focused on soil water deficit values since 1969 to 2008.

During the period 1969-1988 significance decreasing trends were found at many sectors: S4, S6, S7, S8, S10, S1 1 and $\mathrm{S} 12$.

The drought spatial distribution is always different with the exception of south-western area. The 1979 drought affected the whole province while others only some areas. Since 1988 the frequency between droughts became short: 1988, 1989, 1995, 1996, 1999, 2000, 2004, 2005 and 2008.

In spite of no statistical significance, increasing trends are observed in almost all sectors with exceptions of S1, S2, S3 and S6 during the last analyzed decade (1999-2008).

Moderate and severe droughts had the highest annual values of occurrence: 252 and 177 respectively during the forty studied years in Buenos Aires province. The implementation of irrigation is a technology to be considered in the more affected areas.

The results obtained in this paper are according with the words of Moiwo et al (2011) when they said that the method is also of general use to agro-scientists and decision-makers concerned with average soil water storage change at regional scale. Furthermore, the results of this study could find applications in water resources and environmental management and in crop production decision-makings.

\section{Acknowledgements}

The authors wish to thank Juan A. Forte Lay (CONICET) for his useful comments and suggestions with soil water balance.

\section{References}

Allen, R. G., Pereira, L. S., Raes, D., \& Smith, M. (2004). Crop Evapotranspiration. Guidelines for computing crop water requirements. FAO. Irrigation and drainage Paper 56. Roma. $301 \mathrm{pp}$. Retrieved from http://www.engr.scu.edu/ emaurer/classes/ceng140_watres/handouts/FAO_56_Evapotranspiration.pdf

American Meteorological Society (AMS). (2004). Statement on meteorological drought. Bull. Am. Meteorol. Soc., $85,771-773$.

Atlas digital de los recursos hídricos superficiales de la República Argentina; National Water Resources: Buenos Aires, Argentina. (2002). Retrieved January 18, 2011, from http://www.hidricosargentina.gov.ar/CartAct.html\#1

Barros, V., Gonzalez, M., Liebmann, B., \& Camilloni, I. (2000). Influence of the South Atlantic convergence zone and South Atlantic sea surface temperature on interannual summer rainfall variability in South-eastern South America. Theoretical and Applied Climatology, 3(67), 123-133. http://dx.doi.org/10.1007/s007040070002

Forte Lay, J., Scarpati, O. E., \& Capriolo, A. D. (2008). Precipitation variability and soil water content in pampean flatlands (Argentina). Geofisica Internacional, 47(4), 341-354. Retrieved from http://scielo.unam.mx/scielo.php?pid=S0016-71692008000400004\&script=sci_arttext

Hunt, E. D., Hubbard, K. G., Wilhite, D. A., Arkebauer, T. J., \& Dutcher, A. L. (2009). The development and evaluation of a soil moisture index. Int. J. Climatol., 29(5), 747-759. http://dx.doi.org/10.1002/joc.1749 
Liu, S., Mo, X., Zhao, W., Naeimi, V., Dai, D., Shu, C., \& Mao, L. (2009). Temporal variation of soil moisture over the Wuding River basin assessed with an eco-hydrological model, in-situ observations and remote sensing. Hydrol. Earth Syst. Sci., 13, 1375-1398. http://dx.doi.org/10.5194/hess-13-1375-2009

McKee, T. B., Doesken, N. J., \& Kleist, J. (1993). The Relationship of Drought Frequency and Duration to Time Scales, Paper Presented at 8th Conference on Applied Climatology. American Meteorological Society, Anaheim, CA. Retrieved from http://ccc.atmos.colostate.edu/relationshipofdroughtfrequency.pdf

Magrin, G., M. Travasso, W. Baethgen, M. Grondona, A. Gimenez, G. Cunha, ... Rodríguez, G. (2007). Past and Future Changes in Climate and their Impacts on Annual Crops Yield in South East South America. Proc.TGICA Workshop, IPCC WG I. Nadi, Fiji.

Mishra Ashok, K., \& Vijay P. Singh. (2011). Drought Modeling-A Review. Journal of Hydrology, 403(1-2), 157-175. http://dx.doi.org/10.1016/j.jhydrol.2011.03.049

Mishra, A. K., \& Singh, V. P. (2010). A review of drought concepts. J. Hydrol., 391(1-2), 202-216. http://dx.doi.org/10.1016/j.jhydrol.2010.07.012

Moiwo Juana Paul, Fulu Tao, \& Wenxi Lu. (2011). Estimating soil moisture storage change using quasi-terrestrial water balance method. Agricultural Water Management, 102(1), 25-34. http://dx.doi.org/10.1016/j.agwat.2011.10.003

Narasimhan, B., \& Srinivasan, R. (2005). Development and evaluation of soil moisture deficit index (SMDI) and evapotranspiration deficit index (ETDI) for agricultural drought monitoring. Agric. For. Meteorol., 133, 69-88. http://dx.doi.org/10.1016/j.hydrol.2010.07.012

Palmer, W. C. (1968). Keeping track of crop moisture conditions, nationwide: the new crop moisture index. Weatherwise, 21, 156-161. http://dx.doi.org/10.1080/00431672.1968.9932814

Salmi T., A. Mata, P. Anttila, T. Ruoho-Airola, \& Amnell, T. (2002). Detecting trends of annual values of atmospheric pollutants by the Mann-Kendall Test and Sen's slope estimates -the Excel template application MAKESENS. Ilmatieteen laitos Meteorologiska Institutet. Finnish Meteorological Institute Painopaikka: Edita Oyj. Helsinki, $\quad$ Finland. http://cdn.fmi.fi/legacy-fmi-fi-content/documents/MAKESENS_MANUAL.pdf

Scarpati, O., J. A. Forte Lay, \& Capriolo, A. (2011). Drought risk in argentine pampean region. International Journal of Ecology and Development, 18, 1-18. Retrieved from http://ceser.in/ceserp/index.php/ijed/article/view/871

Scarpati, O., J. A. Forte Lay, \& Capriolo, A. D. (2007a). Impacts of ENSO events in soil water moisture in pampean region (Argentina). Revista Geográfica. Pan American Institute of Geography and History. American States Organization, 141, 39-51.

Scarpati, O. E., J. A Forte Lay, L. Spescha, \& Capriolo, A. D. (2007b). Autumn soil water surplus during ENSO events in argentine pampean flatlands. In: Managing water resources in a changing physical and social environment. Robinson, P. J., M-K. Woo and J.A.A. Jones (eds). IGU. Home of Geography. Publication Series, Società Geografica Italiana Rome. 177pp. Part 2. Chapter 4. 27- 36.

Scarpati, O. E., J. A. Forte Lay, \& Capriolo, A. D. (2009). Soil water surplus and ENSO events during the last humid period in Argentine Pampean Flatlands. International Water Journal, 5(2), 181-193. http://dx.doi.org/10.1504/IJW.2009.028725

Scarpati, O. E., J. A. Forte Lay, L. B. Spescha, \& Capriolo, A. D. (2004) Summer Soil Water Storage In Pampean Flatlands (Argentina) During Enso Events. In: The rational use and conservation of water resources in a changing environment. Jones, J.A.A., and T. Vardanian (eds). 1, 38-42. 273 p. Yerevan State University Press.

Spescha, L., J. A. Forte Lay, O. E. Scarpatiy, \& Hurtado, R. (2004). Los excesos de agua edáfica y su relación con el ENSO en la Región Pampeana. Revista de la Facultad de Agronomía, 24(2), 161-167. (In Spanish)

Tang Ch., \& Piechota, T. C. (2009). Spatial and temporal soil moisture and drought variability in the Upper Colorado River Basin. Journal of Hydrology, 379, 122-135. http://dx.doi.org/10.1016/j.jhydrol.2009.09.052

Wilhite, D. A., \& Glantz, M. H. (1985). Understanding the drought phenomenon: the role of definitions. Water Int., 10, 111-120. http://dx.doi.org/10.1080/02508068508686328 